DOI: $10.21554 / \mathrm{hrr} .041808$

\title{
CRITICISM OF THE CONSTITUTIONAL ORGANIZATION OF B\&H
}

\section{Edin Djedović́}

\section{Cantonal Administration for Inspection Affairs of Tuzla Canton}

\author{
Scientific review paper
}

Received: 13.2 .2018

Accepted: 13.3.2018

\begin{abstract}
The Constitution of $B \& H$ and Annex IV of the General Framework Agreement for Peace in Bosnia and Herzegovina is the highest legal and political act in $B \& H$. This document ended the war, and at the same time it is the basis of polity, and a path of further development of $B \& H$. Through analysis of constitutional norms of different types and levels of the $B \& H$ government, especially its structure, the author concludes that certain regulations about common presence of civil and national elements are not consistent. The author highlights urgency to change the Constitution, and he elaborates on different de lege ferenda suggestions for future constitutional solutions. The author especially highlights that the Constitution of Bosnia and Herzegovina is based on such premises which with its adequate application and changing should gradually enable an appropriate legal system which will affirm the sovereignty of Bosnia's citizens, achieve equality of constitutive peoples in the whole Bosnia and Herzegovina, and adequately protect rights of national minorities.
\end{abstract}

Key words: The Constitution of $B \& H$, citizens, constitutive peoples, constitutional changes.

\section{INTRODUCTION}

The General Framework Agreement for Peace in Bosnia and Herzegovina was initiated in Dayton on November 21, 1995, and signed in Paris on December 25, 1995. It was created as a result of a war about which there is not still a mutual agreement in $\mathrm{B} \& \mathrm{H}$ whether it was a war in which the internationally recognized country defended its territory and people against different aggressors or whether it was exclusively a civil war according to the categorization of the International Law. It fits into the context of Bosnia and Herzegovina which is present in the last twenty years, since there is not an agreement to whom $\mathrm{B} \& \mathrm{H}$ as a country belongs, how to organize it, and what is its future. In that sense, even clear and unambiguous norms of the Constitution of Bosnia and Herzegovina as a highest legal and political act in $\mathrm{B} \& \mathrm{H}$ are negated.

The Constitution of $\mathrm{B} \& \mathrm{H}$ is a compromise of different interests. As such, it grants at the same time the highest degree of protection of civil rights, but also discriminates many citizens, constitutive peoples and national minorities, everything in favor of territorialisation of national interests.

\footnotetext{
${ }^{1}$ Correspondence to:

Edin Djedović, Cantonal Administration for Inspection Affairs of Tuzla Canton

Phone: +38761731 129

E-mail: e_djedovich@hotmail.com
} 
There is a lot of literature on the constitutional organization of B\&H. However, the focus and objective of our research is concrete and clear criticism of the constitutional organization of $\mathrm{B} \& \mathrm{H}$ with de lege ferenda suggestions for changing the situation.

We are looking at the problem of how the Constitution of Bosnia and Herzegovina is discriminating and for whom, and whether its regulations about interweaving of civil and national elements are consistent. Therefore, the subjects of the research are branches of legislative, executive and judicial government at the state and entity levels.

The basis of the synthesis are results of researches conducted especially by dogmatic, sociologic and normative methods of law interpretation, and by applying other (logical) methods.

\section{STATE AUTHORITIES}

\section{Parliamentary Assembly of B\&H}

The Parliamentary Assembly of $\mathrm{B} \& \mathrm{H}$ is a representative body which has constitutional and legislative authority in $\mathrm{B} \& \mathrm{H}$ within the scope of law and duty of $\mathrm{B} \& \mathrm{H}$. Due to the complex organization of $\mathrm{B} \& \mathrm{H}$ "The Parliamentary Assembly shows principles of national sovereignty of the three constitutive peoples, and it shows a complex state structure, i.e. the fact that B\&H consists of two entities"(Trnka, 2006, p. 288). It consists of the House of Representatives and the House of Peoples, but this situation is not rare because "in bicameral structure of parliament, which is the most common in the world, interests of citizens are harmonized with other entities in the process of decision-making whether it is about federal units, nationalities, specific social groups or prominent individuals from public or political life" (Trnka, 2006, p. 288).

\section{House of Representatives}

The House of Representatives of the B\&H Parliamentary assembly, which is in fact the House of Commons, gives voice to B\&H citizens' interests. However, in contrast to other democratic countries in which the elections for the House of Commons are held on the basis of equal and general right to vote, election of MPs for the House of Representatives of the Parliamentary Assembly is mediated through entities which causes unequal right to vote.

This is how representation of the citizens of the whole country was disabled, i.e. constituency of the political people in B\&H was bought in question. The House of Representatives has " $42 \mathrm{MPs}$, of which one third is elected from RS, and two thirds from Federation of B\&H" (The Constitution of Bosnia and Herzegovina, Article 4 Act 2). Legitimacy of MPs which represent the citizens as sovereignty holders is endangered by the fact that elections are done through entities, so that the number of MPs from an entity is fixed. Therefore, the principle of equal active and passive right to vote was negated because regardless of growth or decline of an entity's population, they have a fixed number of MPs proportionally. It is not important whether two thirds of the population live in Federation of $\mathrm{B} \& \mathrm{H}$, and one third of the population in RS. Citizens of $\mathrm{B} \& \mathrm{H}$ are reduced to citizens of entities, because on the basis of such election MPs have legitimacy to represent only citizens of 'their' entity, and not all citizens of $\mathrm{B} \& \mathrm{H}$.

\section{House of Peoples}

The House of Peoples has 15 delegates which represent national interests and equality of the three constitutive peoples. In the House of Peoples, there are 5 Bosniaks (which are chosen by Bosniak delegates in the House of Peoples of the Parliament of Federation of B\&H), 5 Croats (which are chosen by Croat delegates in the House of Peoples of the Parliament of Federation of B\&H), 5 Serbs (which are chosen by the National Assembly of RS). The main aim of the House of Peoples which is supposed to be protection ofcollective (national) interests is violated since the election of national representatives is mediated through entities. Therefore, Croats and Bosniaks who live in RS and Serbs who live in Federation of B\&H are discriminated. "If national structure of $\mathrm{B} \& \mathrm{H}$ according to the census from 1991 is taken into consideration, it turns out that almost one third of the electorate cannot choose their representatives to the House of Peoples" (Trnka, 2006, p. 289). If we take into consideration the fact that people of $\mathrm{B} \& \mathrm{H}$ who do not belong to any of the three constitutive peoples cannot be members of the House of Peoples, we clearly come to the conclusion that the House of Peoples negates fundamental constitutional principles about civil rights which are integral part of the Constitution of Bosnia and Herzegovina.

This is the reason why it has to be clearly defined whether fundamental principles about protection of human rights and freedom (individual and collective) whose tributary is B\&H. However, state authorities and the way of decision making disable it. 
This is the reason why it is necessary, among other things, to redefine the composition and role of the House of Peoples which should protect interests of constitutional peoples in $\mathrm{B} \& \mathrm{H}^{2}$ as well as national minorities, i.e. others.

When we compare the system of protection of collectivities' interests in B\&H with those in other multinational countries like Belgium or Switzerland, we can see that they protect all collectivities in the way which agrees with the European Convention on $\mathrm{Hu}-$ man Rights which states that nobody can be discriminated based on skin color, gender, nationality, etc.

European Court of Human Rights has concluded in the subject of Sejdić and Finci that "discrimination on the basis of ethnic origin of a person presents one of the forms of racial discrimination... The Court also thinks that any form of a different conduct which is exceptionally or to critical extent based on ethnic origin of a person cannot objectively be justified in contemporary democratic society which is built on the principles of pluralism and respect of other cultures" (The European Court of Human Rights, High Council, Verdict on the subject of Sejdić and Finci against Bosnia and Herzegovina, Application number 27996/06 i 34836/06 od 22.12.2009, act 43 and 44). In addition, when the sued country became a member of the Council of Europe in 2002 and unreservedly ratified the Convention and its protocols, it agreed arbitrarily to respect relevant standards. "Therefore, the Court concludes that a long-term inability of applicants to run for the House of Peoples of Bosnia and Herzegovina does not have objective and acceptable justification, and therefore it violates the 14th article in relation of 3 th article of the 1st Protocol" (The European Court of Human Rights, High Council, Verdict on the subject of Sejdic and Finci against Bosnia and Herzegovina, Application number 27996/06 i 34836/06 from 22.12.2009, act 57).

\footnotetext{
${ }^{2}$ According to the Third partial decision of the Constitutional Court of $\mathrm{B} \& \mathrm{H}$, all constitutive peoples are constitutive on entity level as well.
}

$\mathrm{B} \& \mathrm{H}$ had enough time to redefine its legislation in order to eliminate this kind of discrimination, but it did not do it. This is the reason why the Court talks about the long-term inability of applicants for election for the House of Peoples. ${ }^{3}$ B\&H has to decide in which way it is going to remove the proved discrimination. The Venice Commission suggests abolition of the House of Peoples and moving the veto for protection of the vital national interests into the House of Representatives. ${ }^{4}$ The House of Peoples could expand and predict appropriate delegating of members of other peoples in $\mathrm{B} \& \mathrm{H} .{ }^{5}$

Anyways, the opinion of the Venetian Commission is that "it is important and urgent to give a clear definition to the vital national interest in the text of the constitution itself... However, it should not be the same as the definition in the entities' constitutions which enables that practically anything can be defined as the vital interest. It should not be excessively broad, but it should be focused on rights which are especially important for those peoples, especially in fields such as language, education and culture" (Opinion of the Venetian Commission CDL-AD(2005)004 from March 11, 2005. Retrieved from the verdict of Sejdić and Finci against Bosnia and Herzegovina).

\footnotetext{
${ }^{3}$ In favor of this, the Court mentioned in the supplement: 'When B\&H became a member of the Council of Europe in 2002, it agreed to reconsider the voting legislature in the light of the norms of the Council of Europe and change things which are necessary in the period of one year and with the help of the European Commission of Democracy through Law (Venetian Commission)', 21st Act of the verdict. And, 'Also, through ratification of the Agreement on stabilization and joining of the EU in 2008, the respondent side agreed to change the Voting Law in the period of one to two years which refers to members of the Presidency of Bosnia and Herzegovina and delegates of the House of Peoples, in order to completely coordinate the law with the European Convention on Human Rights and obligations towards the Council of Europe', Act 49 of the verdict.

${ }^{4}$ 'The role of the House of Peoples is especially negative as a house of veto, where its members see protection of the vital national interest as their main job, without participation in the legislative process. Therefore, it seems that it would be better to move the veto right for protection of vital national interest to the House of Representatives and abolish the House of Peoples' is an opinion of the Venetian Commission from March 11, 2005. Retrieved from the verdict Sejdić and Finci against Bosnia and Herzegovina.

${ }^{5}$ In that case, there is a question, as with an eventual four-member Presidency of $\mathrm{B} \& \mathrm{H}$, which is whether members of minorities in $\mathrm{B} \& \mathrm{H}$ have their vital national interests, i.e. whether their delegates in the House of Peoples have the veto right for protection of such interest, and whether they would be equal then to the constitutive peoples.
} 
Therefore, it is needed to define the vital national interest so that it represents just things in which a people is different from others peoples (language, culture, etc.), and it should prevent that decision on questions which deal with specificities of a people are made through the system of plurality voting.

However, relying on the vital national interest does not present a big problem to the functioning of the Parliamentary Assembly of B\&H, as so-called entity voting does in a way that two thirds of the MPs, i.e. delegates from every entity can prevent passing of any law or decision which is not in their interest. The use of the vital national interest in the House of Peoples of the Parliamentary Assembly of B\&H is in the end in control of the highest judicial unit - Constitutional Court of Bosnia and Herzegovina, whereas entity voting is a regular way of decision making of both Houses of the Parliamentary Assembly of B\&H, and it is not subject to any further control.

Every of the two Bosnian-Herzegovinian entities can in any moment prevent passing of any decision. This absolute veto is paralyzing because "since effective participation of ethnic groups is an important element of democratic institutional structures in multinational country, democratic decision making would be transformed into ethnic domination of one or more groups if for example absolute or limitless power of veto is given to them, thereby enabling a numerous minority represented in government institution to forever impose its will to majority" (Third partial decision of the Constitutional Court of B\&H about constituency of people, number U-5/98 from 01.07.2000, Act 55). $\mathrm{B} \& \mathrm{H}$ will have to change and coordinate its constitutional regulations and legislation during its progress towards the membership of the European Union. However, the specific political situation which exists in $\mathrm{B} \& \mathrm{H}$ leads to the situation in which every eventual change of state organization in the sense of effectiveness of state authority and removal of discrimination is presented as a wish for purely civil, unitary organization which will enable to Bosniaks as the most numerous people to dominate over other two peoples, and it is a priori rejected. In fact, B\&H will never be, and it should not be a country of pure civil democracy because of its specific national structure.

However, being constitutive as a mirror of multinationalism means coexistence, not separation through an exclusive right for a certain territory which is actually created on genocide and ethnic cleansing, and in which they now persistently want to create an illusion of sovereignty and statehood.
We cannot only take into consideration interests of constitutive peoples because there are also interests of Bosnian-Herzegovinian political people, interests of abstract citizens, interests of national minorities, interest of the state, etc. All these interests can be neglected in order to take into consideration interests of constitutive peoples through entities, and this is how the system now functions.

We consider the current situation in B\&H to be unsustainable in the sense of protection and achievement of human rights, especially when the European Convention on Human Rights and Fundamental Freedoms and its protocols are taken into consideration. Constitutional organization of $\mathrm{B} \& \mathrm{H}$ which maintains the maximalist approach to protection of the entities and ruling people(s) in an entity, and the minimalist approach to protection of an abstract citizen and members of others, i.e. effectiveness of the B\&H state will have to change as $\mathrm{B} \& \mathrm{H}$ advances on its path towards the European Union, and as it starts fulfilling conditions which are assigned to it. It especially refers to stronger and more functional capacities of state authorities because $\mathrm{B} \& \mathrm{H}$ as a subject of international law has different laws, but also obligations which it has to fulfill.

$\mathrm{B} \& \mathrm{H}$ is facing various challenges. Primarily, $\mathrm{B} \& \mathrm{H}$ has to cease to be a discriminatory country, and it has to find a way to enable the citizens of $\mathrm{B} \& \mathrm{H}$ to achieve equal right to vote, and enable integration to minorities and inclusion into institutions of the system. On the other hand, it must not violate the constitutional principle of national equality of the constitutive peoples. However, accomplishing constitutive rights has to be taken into consideration in regards to the Third partial resolution about constitution of the people in whole the territory of B\&H. The entity election of the Parliamentary Assembly B\&H is bought into question. However, every attempt to changing the Constitution of Bosnia and Herzegovina in order to improve efficacy of the country and elimination discriminatory regulations is usually considered as an attack to the constitution of peoples and entities.

"It is very desirable that the process of democratic constitutional reforms includes broad consultations and public dialog. In order to be sustainable and legitimate, the process of reforms should be open, and with broad participation and support of citizens. Mechanism for participation and consultation should be included from the very beginning, starting from seeking public opinion about constitutional principles. 
It is of essential importance that a board of domestic experts (as the Constitutional Board of the Parliamentary Assembly) is responsible for making a plan of constitutional proposals. Participation of domestic experts is obligatory, but external suggestions and support should also be available... The elements of the current constitutional regulations which violate the international obligations, endanger financial sustainability of the public sector or enable blockade of the system of decision making, and in that way cause damage to all B\&H citizens, have to be revised" (National Endowment for Democracy, text retrieved from www.sarajevo-x.com on March 26, 2011). Compromise should be made in all of these questions in some new circumstances.

\section{Presidency of Bosnia and Herzegovina}

The Presidency of B\&H is a collective chief of the country, i.e. executive organ within boundaries which the Constitution of Bosnia and Herzegovina set. According to the 5th Article of the Constitution of B\&H "Presidency of B\&H consists of three members: a Bosniak and a Croat who are elected directly from the territory of the Federation, and a Serb who is chosen from the territory of Republika Srpska".

A detailed way of election of the members for the Presidency is settled by the Election Law of B\&H. It seems that Presidency of B\&H represents equality of the three constitutive peoples, but nevertheless it is not the case. Members of the Presidency of B\&H are chosen by entities, not by Bosnian-Herzegovinian constitutive peoples. A Serb member of the Presidency is chosen by citizens of RS, not Serbs, whereas Bosniak and Croat members are chosen by citizens of Federation of B\&H, not Bosniaks and Croats. When we also take into consideration the process of decision making in the Presidency ${ }^{6}$, we come to the conclusion that for example a Serb member of the Presidency represents interests of RS, not Serbs as a constitutive people in the whole $\mathrm{B} \& \mathrm{H}$.

\footnotetext{
${ }^{6}$ Article 5, Act 2. (b states 'A member of the Presidency who voted against certain resolution can say that the resolution is harmful for the vital interests of the entity from which he is chosen.... Such resolution will be immediately submitted to the National Assembly of Republika Srpska if it was expressed by their member, or it will be submitted to Bosniak delegates in the House of Peoples of the Federation if it was said by a Bosniak member; or to Croat delegates in the House of Peoples of the Federation if it was said by a Croat member. If that declaration is supported by two thirds majority of those people in the period of ten days from its submission, the controversial regulation will not be passed.'
}

Situation is similar with Bosniak and Croat member which represent Federation of $\mathrm{B} \& \mathrm{H}$, not Bosniaks or Croats in $\mathrm{B} \& \mathrm{H}$.

Election like this one leads to a situation in which the passive right to vote of citizens of RS which are not members of the national group, as well as citizens of the Federation B\&H who do not declare themselves as Bosniaks or Croats is eliminated. Therefore, although they are constitutive peoples in the whole $\mathrm{B} \& \mathrm{H}$, Serbs from Federation of B\&H, and Bosnians and Croats B\&H from RS cannot run for the Presidency of $\mathrm{B} \& \mathrm{H}$, nor vote for a candidate of their constitutive people. Citizens who are in preamble of the Constitution of $\mathrm{B} \& \mathrm{H}$ marked as others cannot run for a member of the Presidency. The constitution of $\mathrm{B} \& \mathrm{H}$ does not enable it to them.

"Inability for citizens, which do not belong to the three constitutive peoples to be elected in the House of Peoples and Presidency is still in contrast with the protocols 1 and 12 of the ECHR" (Report of the Commission about development of Bosnia and Herzegovina in 2009, reporter for B\&H is Ms. Doris Pack. Retrieved from www.dei-gov.ba on 14.09.2010).

Venetian commission explained the question of the Presidency of B\&H like this: "Collective Presidency is especially unusual question... In this case, distribution of places in state organs among constitutive peoples was a central element of the Dayton Agreement which enabled peace in B\&H... Inclusion of those rules in the text of the Constitution (of Bosnia and Herzegovina) at the timetherefore does not deserve criticism, although it is in contrast with the basis of the Constitution which aims prevent discrimination. This justification has to be taken into consideration in the light of the development of Bosnia and Herzegovina since the Constitution came into force. B\&H has become a member of the Council of Europe, and a country which has to accordingly be regarded through parameters of the common European standards. ... Therefore, it is legitimate to try to shape the election rules which will ensure necessary representation of different groups. However, it has to be done without coming into conflict with the international standards" (Venetian Commission-Opinion about the constitutional situation in Bosnia and Herzegovina and authorities of the High Representative, document CDL-AD (2005)004 from March 11, 2005).

In multinational and post-war country such as $\mathrm{B} \& \mathrm{H}$, the reality is that institutional government ensures appropriate presence of citizens and certain national groups. 
However, protection of human rights of the majority cannot be arranged in a way so that it violates basic human rights of others collectivities. Discrimination which we have mentioned earlier, which is highlighted by Mr. Sejdić and Mr. Finci, also refers to the Presidency of B\&H. They claimed that the difference in treatment "which is exclusively based on race and ethnic origin cannot be justified, and it represents direct discrimination" (European Court for Human Rights, High Council, verdict on the case of Sejdić and Finci against Bosnia and Herzegovina, application number 27996/06 and 34836/06 from 22.12.2009, Act 32).

The respondent side, i.e. the Government of $\mathrm{B} \& \mathrm{H}$ declared that "it is still not time for political system which would be only reflection of the rule of majority, especially when taking into consideration importance of mono-ethnic political parties and long-term international administration in B\&H" (European Court for Human Rights, High Council, verdict on the case of Sejdić and Finci against Bosnia and Herzegovina, application number 27996/06 and 34836/06 from 22.12.2009, Act 32). However, applicants claimed that there is not a possible justification for race and ethnic discrimination ${ }^{7}$, and the time of this exclusion only makes greater the responsibility of the respondent side, and that protection of the three main collectivities in $\mathrm{B} \& \mathrm{H}$ cannot be a justification for the discrimination of other people.

The Human Rights Committee ${ }^{8}$ expressed its concern about B\&H: "The Committee expresses deep concern about the fact that according to the IV and V Articles of the state Constitution only people who belong to a group which is according to law considered one of the Bosnian-Herzegovinian constitutive peoples (Bosniaks, Croats and Serbs), or a group which makes a dominant majority in the territory in which a person has residence (e.g. Bosniaks and Croats in the territory of Federation of B\&H, and Serbs in the territory of Republika Srpska) can be elected to the House of Peoples, or the triple Presidency of Bosnia and Herzegovina.

\footnotetext{
${ }^{7}$ Discrimination based on ethnicity, the Court considered to be a type of racial discrimination in the case Timishev against Russia, number55762/00 and 55974/00, Act 56, ECHR 2005-XII, verdict number 32 .

${ }^{8}$ International Covenant on Civil and Political Rights was adopted and opened to be signed, ratified and entered by the Resolution of the General Assembly 2200 A (XXI) from December 16, 1966. The Covenant became valid on March 23, 1976. In the Article IV, Act 28 of the Covenant the Human Rights Committee was established.
}

The existing legal structure therefore excludes all people who declare themselves as 'others', or people who belong to national minorities or ethnic groups which are not Bosniaks, Croats or Serbs from the House of Peoples and Presidency" (Concluding considerations of the Committee retrieved from the verdict of Sejdić and Finci against Bosnia and Herzegovina, p. 14 and 15).

The Great Chamber of the European Court of Human Rights made a decision about the case of Sejdić and Finci against Bosnia and Herzegovina on December 22, 2009 in which it was decided (with 16 votes for and 3 against) that "the controversial precondition which refers to the eligibility for candidacy for the Presidency represents violation of the 1st Article of the 12th Protocol" (European Court for Human Rights, High Council, verdict on the case of Sejdić and Finci against Bosnia and Herzegovina, application number 27996/06 i 34836/06 from 22.12.2009, Act 55). "After ethic conflict of law difference which is based on ethnic affiliation, tensions can be worsened, instead of strengthening constructive and sustainable relationships among all ethnic groups which is necessary for sustainability of a multi-ethnic country" (Submission of AIRE center (Center for Advice on Individual Rights in Europe), as a third party in the case of Sejdić and Finci against Bosnia and Herzegovina from 15.08.2008, p. 30).

"There is a possibility that rules about Presidency are transformed so that they are compatible with the international standards, but which political balance in the country" (Venetian Commission - Opinion on the constitutional situation in Bosnia and Herzegovina and authorities of the High Representative, document CDL$\mathrm{AD}$ (2005)004 from March 11, 2005. Retrieved from the verdict of Sejdić Finci against Bosnia and Herzegovina, pg. 19). Appropriate constitutional inclusion of the 'others' in the Presidency of B\&H does not violate the status of constitutive peoples, but it will lead to the situation in which $\mathrm{B} \& \mathrm{H}$ ceases to function as a discriminatory country.

There are different opinions about how to redefine the Presidency of B\&H which come from different domestic and foreign, especially political actors. It is almost impossible to introduce a suggestion which was not already popular, and about which a public opinion has not been made. Anyway, we think that it is important to decrease the role and importance of the Presidency because it is neither effective nor functional, and the executive government positioned in the Council of Ministersin which constitutive people are represented (to which a member of others would be added), andwhich has an effective apparatus (administration) to effectively perform executive government. 
All this is not possible if members of the Presidency are chosen directly which does not give them strong legitimacy. The problem of active and passive right to vote of Serbs in Federation of B\&H and Bosniaks and Croats in RS could be solved if the state Parliamentary chose members of the Presidency (e.g. the both Houses together). Therefore, the discrimination would be eliminated because members of the Presidency would also be chosen by representatives of others, Serbs from Federation of B\&H and Bosniaks and Croats from RS, i.e. by members of the House of Representatives which they can choose. In the case the triple Presidency would be abolished, and a system of one president introduced, every next president would be from a different constitutive people or a member of others. It is important to find a way which would effectively disable the current situation in which "members of the Presidency still represent a personal standpoint on international forums which usually does not maintain overall policy of Bosnia and Hercegovina" (Report of the Commission of European Communities on development of Bosnia and Herzegovina in 2009).

\section{NECESSITY FOR CONSTITUTIONAL CHANG- ES IN B\&H}

The Dayton Agreement was successful in its primary role which is to stop the war, and stabilization in the territory of $\mathrm{B} \& \mathrm{H}$. When we take into consideration different agreements which were proposed during the war in $\mathrm{B} \& \mathrm{H}$, we think that the Dayton Agreement secured interests of $\mathrm{B} \& \mathrm{H}$ and its citizens. However, conditions have changed since then, and therefore priorities of $\mathrm{B} \& \mathrm{H}$ which is now a member of the Council of Europe, and wants to join the EU have changed. Therefore, certain constitutional regulations which once could have been accepted in order to stop the war are now unsustainable. The verdict of the European Court of Human rights on the case of Sejdić and Finci against B\&H in December of 2009 confirm it in the best way. It only made a decision about the factthe Constitution of $\mathrm{B} \& \mathrm{H}$ is discriminatory against minorities. However, the Constitution of B\&H is also discriminatory against constitutive peoples depending on the entity in which they live.

There have been different attempts to change the Constitution of B\&H. There have been several important meetings on this topic of domestic as well as foreign political officials. Certainly the most known are 'Aprilski paket' from 2006, 'Sporazum iz Pruda' from 2008, and 'Butmirski proces' from October, 2009.
The process of constitutional changes in $\mathrm{B} \& \mathrm{H}$ is the topic about which we are informed through media, different political and scientific meetings, professional and scientific articles, etc. The Venetian Commission $^{9}$ gave opinions and suggestions about the necessity of constitutional changes in $\mathrm{B} \& \mathrm{H}$.

Therefore, it is difficult to offer an 'original' opinion on this topic, without it being already represented in the politics. Throughout the study, we have critically touched upon certain question of the constitutional organization of $\mathrm{B} \& \mathrm{H}$ and proposed different constitutional changes. Now we will try to summarize it, and present several possible models of constitutional changes in $\mathrm{B} \& \mathrm{H}$ with appropriate comments.

We ground the necessity of constitutional changes on the fact that the Constitution of $\mathrm{B} \& \mathrm{H}$ represents secure constitutionality. It is the result of unlawful power. The Constitution of $\mathrm{B} \& \mathrm{H}$ incorporates all possible international acts of human rights, and at the same time makes unbelievable discrimination. The constitution of $\mathrm{B} \& \mathrm{H}$ defines the continuity of $\mathrm{B} \& \mathrm{H}$ as a country whose citizens decided for restoration of its sovereignty with free will, and at the same time leads the country and citizens into a dangerous position of functioning and survival. All this was enabled by a shameful role of the international community which as an answer to the question of dissolution of SFRY offered democracy through Arbitration Commission (November 1991), and after recognition of B\&H as a sovereign country did not do anything to protect it, but through passive role as a solution of the peace process at the end offered ethnocracy (November 1995). In just four years, B\&H went from democracy and citizens which renewed its sovereignty in the direction which saved the country and its continuity, but with constitutional elements which paralyze its democratic capacity.

The absolute mechanism of protection of constitutive peoples and their teritorialization minimalized the role of Bosnian-Herzegovinian citizens who are not even in the Constitution of B\&H explicitly mentioned as sovereignty holders. However, the Constitution of $\mathrm{B} \& \mathrm{H}$ is normed by a broad range of possibilities towards democratization which are long lasting, and in B\&H often impossible, process.

\footnotetext{
${ }^{9}$ Venetian Commission, whose first name is European Commission of Democracy through Law, is an advisory body of the Council of Europe for constitutional questions. See more in the text VENECIJSKA KOMISIJA which is published by Zajednička Služba of secretariat of the Parliamentary Assembly of B\&H in 2009. Retrieved from www.parlament.ba on 04.01.2016. or from the website www.venice.coe.int
} 
The contradiction of norming international acts of human rights protection while at the same time setting consociation ethnocracy is in the fact that the system of special values should be stabilization of the country after the peace agreement, and the system of progressive values, which would finally balance common values of the state and citizens with the special values, should be its future. However, obstructions of progress are constant and the struggle is long lasting, but not impossible.

Constitutional changes in $\mathrm{B} \& \mathrm{H}$ can be done through 'sets' if changes or just certain cosmetic alternations can be initiated by the international community or local ethno-political leaders. However, constitutional changes have to bring necessary functioning and democracy which should enable to $\mathrm{B} \& \mathrm{H}$ to have elements and mechanisms primarily as counterweight to clear specific elements in B\&H.

Democracy of society should at the same time lead to adequate realization of active and passive voting right with which the democratic system, based on the citizens of $\mathrm{B} \& \mathrm{H}$, would be qualitatively distanced from the process of accomplishing the interests of constitutive peoples. It would gradually develop constitutional patriotism through the feeling of affiliation to BosnianHerzegovinian political (state) nation of equal citizens. Therefore, it would establish a democratic system and capacity of government, together with collectivities and their interests which would be predominant. Besides democratization of the whole society and establishment of the civil values and actions, it would separate in a coexistent way and enable accomplishment of civic and national interests through election of representatives and processes of decision making which would at the same time abolish the discrimination in the electoral process.

Functionality and democracy have the role of the propellant power which would improve the relationships between civil and national values in the constitutional system of $\mathrm{B} \& \mathrm{H}$ which now functions as a paralyzed ethnic-territorial misbalance in favor of special values which are grounded on absolute blockade of the process of decision making, ethnic territorialization of constitutive peoples, rejection of citizens as a component of the constitutional process, and creating an illusion of sovereignty and statehood of entities. New democratic processes in B\&H should gradually work on correction of the misbalance and adequate balancing of the relationship which would be somewhere in the 'middle', and which would enable parallel achievement of both interests in full form in federal constitutional organization.

\section{PROPOSALS FOR DE LEGE FERENDA CON- STITUTIONAL CHANGES}

Considering Bosnian-Herzegovinian political reality, we cannot expect some significant constitutional changes because of the way in which they are made. However, we can currently analyze a possible process of changes through the prism of the verdict Sejdić and Finci against B\&H.

\section{Presidency of B\&H}

The process of constitutional changes can be performed in several ways. Our proposals would be the following: - Abolition of three-member presidency and establishment of an inocular president, with the situation in which election of a president would be regulated in a way that four consecutive different presidents cannot be from the same constitutive peoples or among 'others', which means that for example the first president of B\&H would be a member of others, then a Serb, a Croat and Bosniak and so on; this method should follow the election of the president of $\mathrm{B} \& \mathrm{H}$ in the Parliamentary Assembly of B\&H and decrease their authorities, which would solve the case of Sejdić/Finci. - Introduction of the system with one president and three vice presidents from different constitutive peoples and minorities which would with appropriate rotations and accompanying constitutional regulation solve the problem of Sejdić/Finci, and also decrease the constitutional importance of the presidency.

- Introduction of an additional member of the Presidency among others, i.e. establishment of four-member presidency which opens many further question such as the way of election of the "new" member, the way of decision making, and the question of the veto of others.

- Retention of the current structure with formal enabling to members of others to be elected to this position, although it would be difficult for them to be elected to this position.

- Regardless the structure of changes, we think that the role and importance of the Presidency of B\&H should be decreased in the way that election of its members is done by the Parliamentary Assembly of B\&H.This would decrease its legitimacy because members of the Presidency would not be chosen by citizens, and the current discriminatory regulations would be abolished because in the election of members of the Presidency would take part both houses of the Parliamentary assembly of B\&H, i.e. members of others, Serbs from Federation of $\mathrm{B} \& \mathrm{H}$, and Bosniaks and Croats from RS would also participate. 
In fact, members of the House of Representatives whom they can choose would take part in the election, and the main role of the executive government should be given to the Council of Ministers of B\&H to which it is necessary to insure adequate administrative structure to perform its duties, and which primarily as a professional organ should maintain proportional structure of $\mathrm{B} \& \mathrm{H}$ population.

\section{The House of Peoples of the Parliamentary As- sembly of $\mathbf{B} \& \mathbf{H}$}

When it comes to the House of Peoples, we recommend the following:

- Make the makeup of the House of Peoples larger for the members of others in the whole territory of $\mathrm{B} \& \mathrm{H}$

- Enable to all members of constitutive peoples to accomplish their passive voting right for this House in a way that more than three or four members of one constitutive people cannot be from the same entity, i.e. number of delegates from every entity would be normed, so that national representation and protection are not linked to one entity, but to one people in the whole country, at least in the election of one member. Criticism of nationalist for this proposal would be that a Serb from Federation of $\mathrm{B} \& \mathrm{H}$ is not a true Serb as the one from $\mathrm{RS}$, and the same applies to Bosniaks and Croats in RS. However, if only one or two members of the House of Peoples were chosen as Serbs from the Federation of B\&H and in the same way Bosniaks and Croats from RS, they would not change the structure and the way of decision making in the House, but just add a new way of thinking and representing of constitutive peoples in the constitutional system of $\mathrm{B} \& \mathrm{H}$, and at least partially annul the consequences of the genocide and ethnic cleansing, and it would bring people together in accordance with the Third partial decision about constituency of peoples.

- Besides national clubs in the House of Peoples, establish also clubs of entities (determine a minimal number of delegates for each entity, and if it is not possible to abolish ethnic voting in the House of Representatives of the Parliamentary Assembly, then it should be moved to the House of People and used through entity clubs. In this case, the vital national interest of constitutive peoples, but also interests of entities would be accomplished in the House of Peoples, whereas the House of Representatives would remain a true representative of citizens of $B \& H$ (with a supplement with which a number of mandates is balanced in regards to the number of voters from both entities as voting units, which would ensure equal active and passive voting right for citizens of $\mathrm{B} \& \mathrm{H}$ ). Therefore, this would adequately separate interests of citizens of $\mathrm{B} \& \mathrm{H}$ from interests of constitutive peoples and entities, and through a constitutional system on state level we would get by an election process a 'citizen of B\&H' and their representative.

\section{CONCLUSION}

Criticism of this proposal of constitutional changes would probably be that it is not possible, applicable or that it discriminates certain people. However, our counterargument would be that any proposal in $\mathrm{B} \& \mathrm{H}$ could not be accepted which is proved by the proposals of constitutional changes until now about which 'leaders' of constitutive peoples discussed outside of the usual parliamentary procedure. The reason is that it is currently in B\&H difficult to find a solution which suit all the three constitutional peoples, citizens of $\mathrm{B} \& \mathrm{H}$ and others which would be valid and protect national interests, but the same time strengthen the status of citizens and contribute to the functional government on state level. Therefore, every (even the one we proposed) proposal for changes of the Constitution of $\mathrm{B} \& \mathrm{H}$ has to compromise, and it has to get approval of the national collectivities which was for example in the period 2014 -2017 in contrast with their real political interests. On the other hand, the state sovereignty of B\&H as a member of the international community, i.e. as a member of United Nations is limited by the obligations which it took by its Constitution, and which potentiate original rights of a sovereign people as citizens of a political community. The Constitution of $\mathrm{B} \& \mathrm{H}$ is grounded on these premises which by their adequate application and changing should gradually enable an appropriate legal system which would affirm sovereignty of citizens of $\mathrm{B} \& \mathrm{H}$, achieve equality of constitutive peoples in the whole territory of $\mathrm{B} \& \mathrm{H}$, and adequately protect rights of national minorities. Therefore, we will as a finishing consideration of the constitutional organization of $\mathrm{B} \& \mathrm{H}$ define two necessary steps towards establishment of a 'normal' democratic European country. 
First step - it is necessary to write in the Constitution of $\mathrm{B} \& \mathrm{H}$ all authorities which $\mathrm{B} \& \mathrm{H}$ has at the moment of application for membership to European Union at the beginning of 2016. It refers to all the changes which have happened since 1995 in favor of $\mathrm{B} \& \mathrm{H}$ and which in sui generis constitutional situation of $\mathrm{B} \& \mathrm{H}$ represent the constitution in material sense, and which are of primary importance for B\&H. That would be the first positive step towards a functional country.

Second step - refers to the second common element which are citizens of B\&H. B\&H needs besides all international acts which are part of its Constitution one new 'charter' which will detach citizens from race, religion, ethnicity, national affiliation and language which serve as basis for political identity and differences, and instead list them as citizens - equal and abstract holders of sovereignty and legitimacy of all $\mathrm{B} \& \mathrm{H}$ government. It is necessary to define citizens as holders of sovereignty in the composition itself which has primarily legal, but also sociological, political and every other importance, and in that sense and on these foundations build balance between common and special values.

When we look from the time perspective of (19922017) at the referendum question which was basis of $\mathrm{B} \& \mathrm{H}$ renewed sovereignty, and which was "Do you want a sovereign and independent Bosnia and Herzegovina, a country of equal citizens, peoples of B\&H Muslims, Serbs, Croats and members of other peoples which live in it?'. There are two main consequences from this question: all citizens which answered to this question with YES can be satisfied because $\mathrm{B} \& \mathrm{H}$ is a sovereign and independent country (at least in its foundations), whereas all citizens who answered with NO can be satisfied because B\&H is not a country of equal citizens, peoples of $\mathrm{B} \& \mathrm{H}$ and members of other peoples.

\section{REFERENCES}

European Court of Human Rights, High Council, Verdict on the case of Sejdić and Finci against Bosnia and Herzegovina, Application number 27996/06 and 34836/06 from 22.12.2009.

International Covenant on Civil and Political Rights from 1966.

National Endowment for Democracy, text retrieved from www. sarajevo-X.com on March 26, 2011.

Opinion of the Venetian Commission CDL-AD(2005)004 from March 11, 2005. Retrieved from the verdict of Sejdić and Finci against Bosnia and Herzegovina.

Report of the European Commission on development of Bosnia and Herzegovina in 2009, reporter for B\&H is Ms. Doris Pack. Retrieved from www.dei.gov.ba on 14.09.2010.

Submission of AIRE center (Center for Advice on Individual Rights in Europe), as a third party in the case of Sejdic and Finci against Bosnia and Herzegovina from 15.08.2008.

Text VENECIJSKA KOMISIJA which is published by Zajednička Služba of secretariat of the Parliamentary Assembly of B\&H in 2009. Retrieved from www.parlament. ba on 04.01.2016. or from the website www.venice.coe. int.

The Constitution of B\&H, Dayton Peace Agreement - Ustav Bosne i Hercegovine, brochure printed by USAID, date not mentioned.

Third partial decision of the Constitutional Court of B\&H about constituency of peoples, number U-5/98 from 01.07.2000.

Trnka, K. (2006). Ustavno pravo, Fakultet za javnu upravu, Sarajevo. 